КОСМИЧЕСКИЕ МОНИТОРИНГОВЫЕ НАБЛЮДЕНИЯ НЕФТЕГАЗОПРОЯВЛЕНИЙ МОРСКИХ АКВАТОРИЙ: ГЕОЛОГИЧЕСКИЕ И ГЕОЭКОЛОГИЧЕСКИЕ АСПЕКТЫ

\author{
Аковецкий В.Г., РГУ нефти и газа (НИУ) имени И. М. Губкина \\ E-mail: geoinforisk@mail.ru
}

\begin{abstract}
Аннотация. Рассмотрены основные аспекты разработки инновационных технологий при реализации Программы «Цифровой экономики» в областях, относящихся к развитию нефтегазового комплекса. Особое внимание уделено направлениям, связанным с созданием российских центров обработки данных, внедрению цифровых платформ работы с данными, созданию эффективной системы сбора, обработки, хранения и предоставления потребителям пространственных данных на основе систем дистанционного зондирования Земли (ДЗ3). Представлена разработанная методика проведения космических мониторинговых наблюдений нефтегазопроявлений при реализации проектов освоения ресурсов углеводородов на шельфе морских акваторий.
\end{abstract}

Ключевые слова: космический мониторинг, нефтегазопроявления, индикаторы, морские акватории, залежи.

\title{
SPACE MONITORING AND OBSERVATIONS OF OIL AND GAS SHOWS ON THE SEA AREAS: GEOLOGICAL AND GEO-ECOLOGICAL ASPECTS
}

Akovetskiy V.G., Gubkin Oil and Gas University

E-mail: geoinforisk@mail.ru

\begin{abstract}
The main aspects of the development of innovative technologies in the implementation of the Digital Economy Program in areas related to the development of the oil and gas sector are considered. Particular attention is paid to areas related to the creation of Russian data processing centers, the introduction of digital data processing platforms, the creation of an effective system for collecting, processing, storing and providing users with spatial data based on Earth remote sensing systems. The developed methodology for conducting space monitoring observations of oil and gas shows during the implementation of projects for the development of hydrocarbon resources on the shelf of marine areas is presented.
\end{abstract}

Keywords: space monitoring, oil and gas shows, indicators, marine areas, deposits 
Актуальные проблемы нефти и газа • Вып. 4(23) 2018 • http://oilgasjournal.ru

Труды Международной конференции «Дегазация Земли: геология и экология - 2018»

Современные тенденции развития нефтегазового комплекса непосредственно связаны с освоением морских месторождений нефти и газа. Этот вектор развития стал активно проявляться в начале XXI века, когда общий уровень добычи нефти и газа на шельфе к 2015 году вышел на уровень 30\%. Одновременно грузооборот морского транспорта составил $75 \%$, а вылов морепродуктов обеспечил $25 \%$ белков животного происхождения.

Следует отметить, что реализация проектов на шельфе морских акваторий требует значительно больших экономических вложений, чем на сухопутных территориях. Увеличение вовлечения морских акваторий в производственную деятельность повышает уровень антропогенного воздействия на природные компоненты окружающей среды Мирового океана. Данное обстоятельство требует повышенного внимания к рискфакторам, определяющим эффективность реализации проектов освоения углеводородных ресурсов. Именно эти проекты являются экономически трудозатратными, а также оказывают значительное влияние на состояние окружающей среды.

Важное место при их реализации отводится новым инновационным подходам, базирующимся на использовании определяющих элементов программы «Цифровой экономики» в областях, относящимся к развитию нефтегазового комплекса. Решение отмеченных задач требует системного похода, основанного на создании единого информационного пространства, объединяющего данные из открытых геопорталов и данные геоинформационной среды проекта, получаемые в ходе его реализации. Особого внимания при этом заслуживают направления исследований, связанные с созданием центров обработки данных на основе систем дистанционного зондирования Земли (ДЗЗ). Здесь происходит переход от задач отображения земной поверхности на основе систем дистанционного наблюдения к задачам объектно-ориентированной интерпретации отдельных объектов и процессов. В связи с этим, актуальными становятся задачи, учитывающие специфику реализуемых проектов и связанные с получением информации о состоянии территорий в определенные моменты времени. Длительность промежутка времени и частота получения информации, а также охват территории определяются свойствами наблюдаемых объектов и стадией реализации проекта. Особенное место среди них занимают проекты, связанные с освоением месторождением нефти и газа на шельфе морских акваторий, что определяется значительной вариативностью решаемых целевых задач, включающих [1]: 
Актуальные проблемы нефти и газа • Вып. 4(23) 2018 • http://oilgasjournal.ru

Труды Международной конференции «Дегазация Земли: геология и экология - 2018»

прогноз и поиск морских месторождений нефти и газа;

разработку, обустройство и эксплуатацию морских месторождений нефти и газа;

проектирование, строительство и эксплуатацию подводных трубопроводов;

морскую транспортировку, переработку и реализацию продуктов из нефти газа.

В частности, в задачах поиска залежей нефти и газа нефтегазопроявления выступают в качестве геологического индикатора, а при строительстве и эксплуатации добывающих платформ, подводных трубопроводных систем, хранения и танкерной транспортировки они выступают геоэкологическим индикатором загрязнений морских вод. Отмеченная двойственность нефтегазопроявлений требует использования адаптивных методов их интерпретации, учитывающих особенность решаемых задач.

Целью представленного доклада является оптимизация моделей интерпретации мониторинговых наблюдений нефтегазопроявлений на морских акваториях на основе геоинформационной среды территории, учитывающей геологические и геоэкологические аспекты освоения морских месторождений нефти и газа.

Достижение указанной цели предполагает решения задач, обеспечивающих (рис.1): построение геоинформационной среды исследуемой территории;

локализацию зоны поиска объекта съемки на основе геоинформационной среды; получение изображений исследуемой территории посредством систем Д33; интерпретацию изображений объектов на исследуемой территории; подготовку паспортов параметров наблюдаемого объекта.

Ключевое место при их решении отводится использованию комплексных методов интерпретации объектов и процессов, реализуемых в ходе визуальных, автоматизированных и автоматических режимов наблюдений

Следует отметить, что определяющую роль в предлагаемой схеме организации интерпретации мониторинговых наблюдений нефтегазопроявлений морских акваторий отводится геоинформационной среде проекта. Она представляет собой совокупность геопространственных данных, обеспечивающих построение моделей природных и техногенных объектов на разных стадиях реализации проекта.

Структурно она включает геоинформационные модели территории и объектноориентированные модели исследуемого объекта: на планетарном уровне (PL), уровне государства (GOS), уровне морской акватории (MAQ), уровне объекта источника (геологического, геоэкологического (техногенного). 
Труды Международной конференции «Дегазация Земли: геология и экология - 2018»

В формализованном виде геоинформационную среду GSt опишем множеством

$$
G S_{t}(P L, G O S, M A Q)=\bigcup_{t \in T}\left(G S_{t}(\text { Ter })_{P L, G O S, M A Q}, G S_{t}(O b j)_{P L, G O S, M A Q}\right),
$$

где GSt(Ter)PL, GOS, MAQ, GSt(Obj)PL, GOS, MAQ - подмножества, содержащие параметры территориальных и объектно-ориентированных моделей геоинформационной среды $\mathrm{GS}_{\mathrm{t}}$ на момент времени $\mathrm{t}$ периода T.

Территориальные модели геоинформационной среды включают: топографические, метеорологические, гидрологические, гидрохимические и геофизические параметры объектов. В общем виде геоинформационную среду территориальных моделей $\mathrm{GS}_{\mathrm{t}}(\mathrm{Ter})$, представим в виде выражения выражения

$G S_{t}($ Ter $)=$

$\cup_{t \in T}\left(G S_{t}(T o p)_{P L, G O S, M A Q}, G S_{t}(G d l)_{P L, G O S, M A Q}, G S_{t}(G c h)_{P L, G O S, M A Q}, G S_{t}(G e o f)_{P L, G O S, M A Q}\right.$,

где $\mathrm{GS}_{\mathrm{t}}(\mathrm{Top})_{\mathrm{PL}}, \mathrm{GOS}$, MAQ, GS $(\mathrm{Gdl})_{\mathrm{PL}}, \mathrm{GOS}, \mathrm{MAQ}, \mathrm{GS}_{\mathrm{t}}(\mathrm{Gch})_{\mathrm{PL}}, \mathrm{GOS}$, MAQ - подмНожества, содержащие параметры топографических, гидрологических, геохимических и геофизических моделей территорий геоинформационной среды $\mathrm{GS}_{\mathrm{t}}$ на момент времени $\mathrm{t}$ периода Т.

Топографические параметры включают цифровые топографические модели дна морских акваторий; цифровые модели рельефа, представленные в виде регулярной сетки высот или нерегулярной триангуляционной сети; пространственные координаты подводных геологических и техногенных объектов.

К гидрологическим параметрам относятся температура и соленость, необходимые для расчета плотности морской воды, а также скорость и направление течений на различных горизонтах. К гидрологическим параметрам также относятся основные оптические характеристики (интегральная прозрачность, спектральное поглощение и рассеяние, облученность на разных горизонтах) определяющие световые условия фотосинтеза морских организмов. Данные параметры могут измеряться постоянно на выбранных горизонтах или в режиме периодического вертикального зондирования водной толщи.

К важнейшим гидрохимическим показателям, характеризующим состояние морской среды относятся: концентрация растворенного кислорода, содержание растворенных в морской воде нефтепродуктов, содержание различных форм органического и минерального фосфора, азота, содержание растворенных органических 
Труды Международной конференции «Дегазация Земли: геология и экология - 2018»

веществ. Среди данных параметров содержание кислорода и растворенного органического вещества может быть измерено датчиками в режиме реального времени или в режиме периодического зондирования. Остальные гидрохимические характеристики определяются в пробах воды в лабораторных условиях.

К геофизическим параметрам следует отнести сейсмические сигналы от близких землетрясений, а также вызванные наведенной сейсмичностью, вследствие нарушения тектонического равновесия при извлечении больших масс углеводородного сырья. При анализе сейсмических записей может быть произведена оценка степени напряженности массива в окрестностях буровых скважин, что является важной характеристикой в задачах обеспечения геоэкологической безопасности. Следует отметить, что даже слабые сейсмические события могут вызвать нефтегазопроявления на поверхности акватории.

Объектно-ориентированные модели нефтегазопроявлений в задачах мониторинговых наблюдений связаны: с источниками образования; условиями появления на морской поверхности; с условиями дистанционного зондирования; с моделями интерпретации $[8,9]$.

Это позволяет объектно-ориентированную модель геоинформационной среды мониторинговых наблюдений нефтегазопроявлений представить выражением вида

$$
G S_{t}(O b j)_{I s t, \text { Surf,Im,Int }}=\bigcup_{\mathrm{t} \in \mathrm{T}}\left(\mathrm{GS}_{\mathrm{t}}(G l)_{\text {Ist,Surf,Im,Int }}, G S_{t}(G e)_{\text {Ist,Surf,Im,Int }}\right),
$$

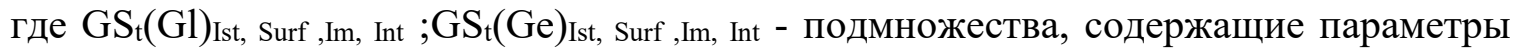
геологических и геоэкологических моделей источников нефтегазопроявлений (Ist), поверхностных моделей нефтегазопроявлений (Surf), моделей изображений нефтегазопроявлений $(\mathrm{Im})$ и моделей их интерпретации на момент времени $\mathrm{t}$ периода исследования Т.

На исследуемой территории строятся объектно-ориентированные модели источников нефтегазопроявлений: геологические (природные) и геоэкологические (техногенные).

Важное место при организации мониторинговых наблюдений должно уделяться физическим свойствам наблюдаемых объектов. При наблюдении нефтегазопроявлений эти свойства непосредственно связаны с геологическими и геоэкологическими источниками их происхождения. 
Актуальные проблемы нефти и газа • Вып. 4(23) 2018 • http://oilgasjournal.ru

Труды Международной конференции «Дегазация Земли: геология и экология - 2018»

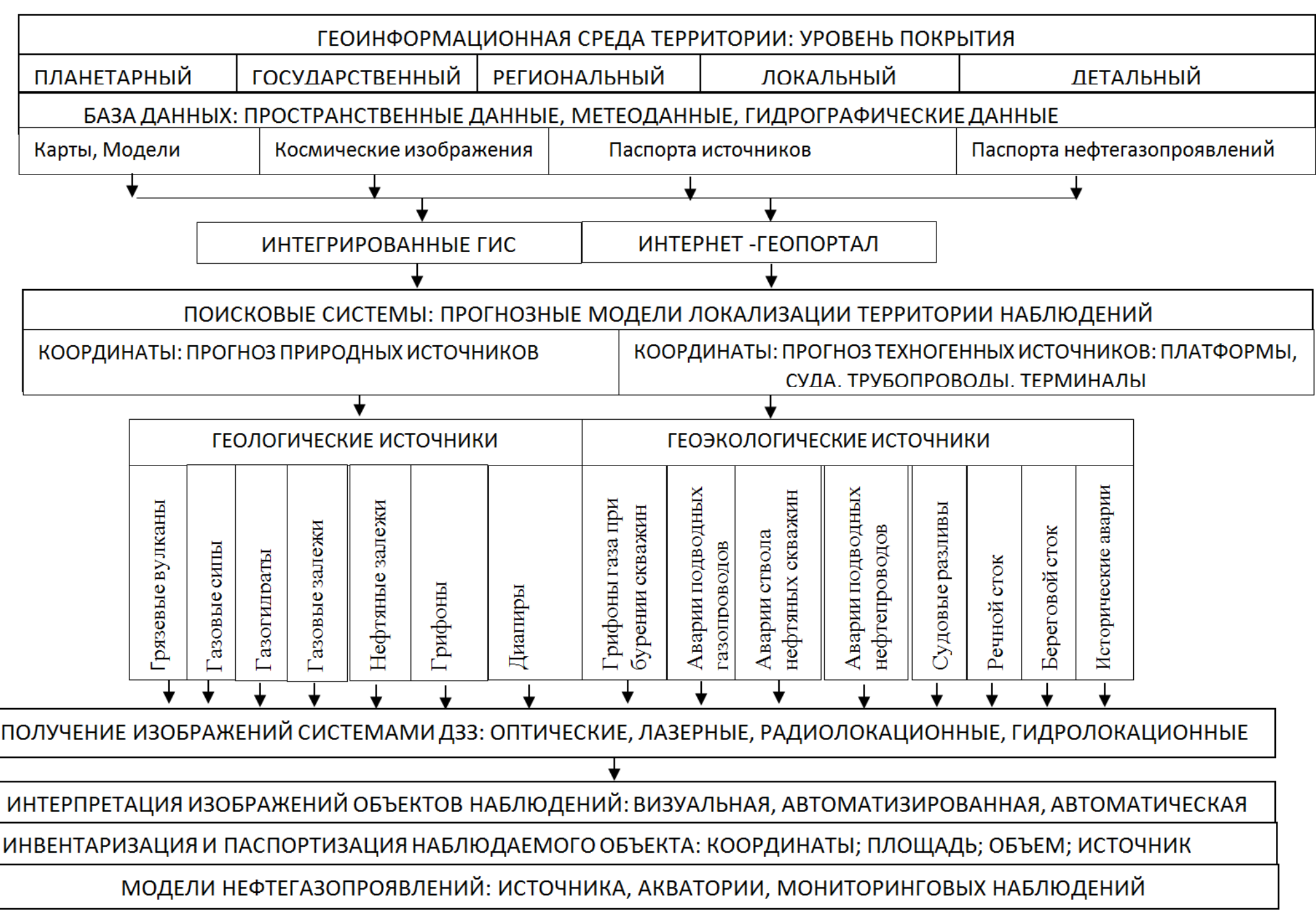

Рис. 1. Система мониторинговых наблюдений нефтегазопроявлений морских акваторий 
Актуальные проблемы нефти и газа • Вып. 4(23) 2018 • http://oilgasjournal.ru

Труды Международной конференции «Дегазация Земли: геология и экология - 2018»

В перечень геологических источников нефтегазопровлений входят: грязевые вулканы, газовые сипы, газогидраты, газовые залежи, нефтяные залежи, грифоны, диапиры, тектонические разломы (рис.3).
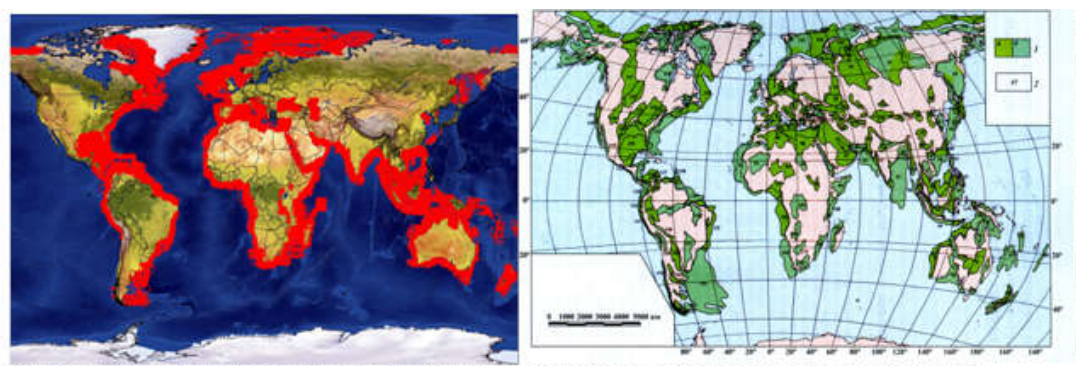

Нефтепроявления на космических снимках [10] Основные нефтегазоносные провинции [5]

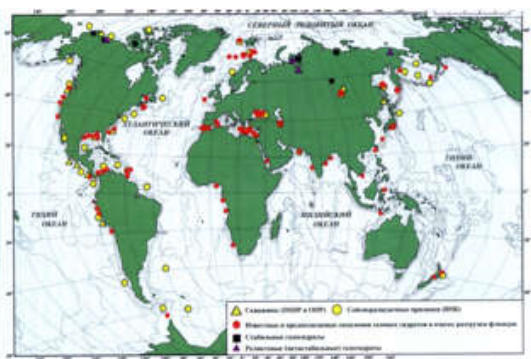

Известные гидратопрояв.ления [6]

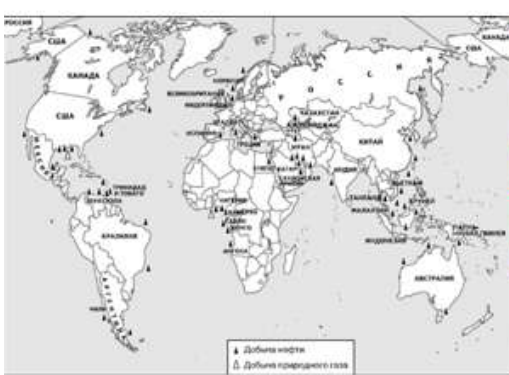

Районы добычи нефти и газа

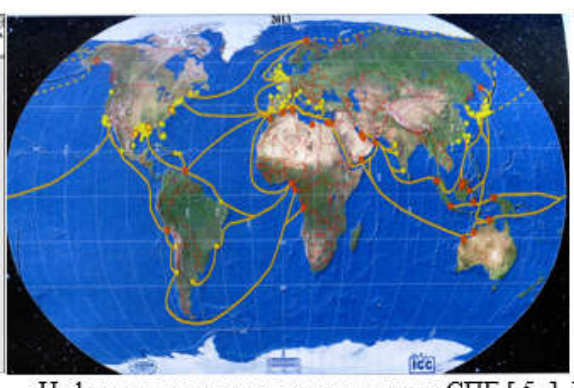

Нефтегазотрансппортные системы СПГ [ 5 ] Катастрофы и аварийные разливы нефти [ 5 ]

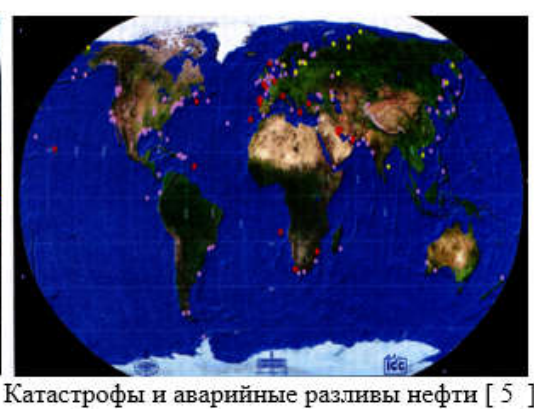

Рис.2 Фрагмент объектно-ориентированных моделей источников нефтегазопроявлений (планетарный уровень)

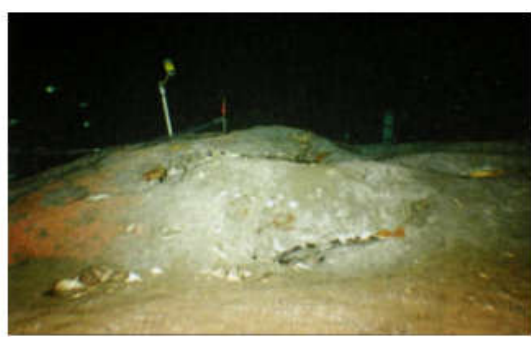

Газогидратный холм в Мексиканском заливе

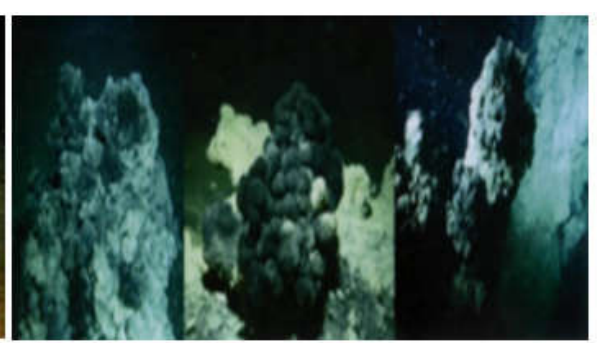

Внешний вид газогидратов [5]

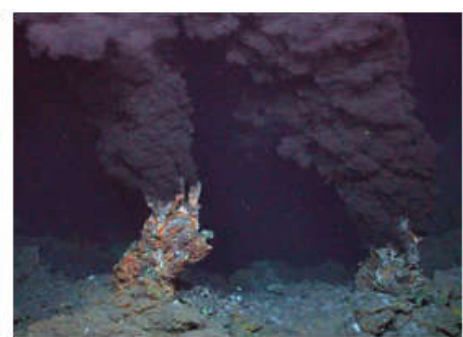

Грязевой вулкан. Черное море

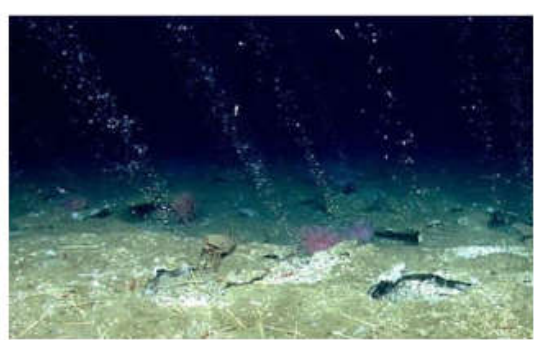

Выбросы метана

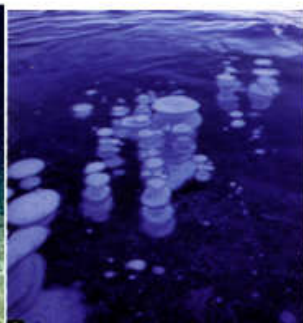

Пузырьки метана в припайном льду [5]
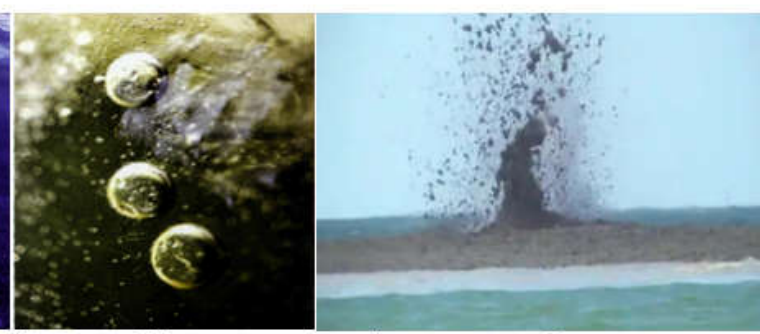

Азовское море. Грязевой вулкан

Рис.3. Фрагмент образцов эталонов источников нефтегазопровлений морских акваторий

Грязевые вулканы (или сальзы) - это разнообразные по форме геологические образования, постоянно или периодически извергающие на земную поверхность грязевые массы и газы, часто с водой и нефтью. Они представляют небольшие пологие сопки, высотой от 2 м до 50-60 м. Конус грязевой сопки сложен продуктами ее извержения, 
сопочной брекчией, в которых удается различить отдельные потоки. На вершине расположен кратер от 0,5 м до 2-3 м в диаметре. По составу продуктов извержения грязевые вулканы обнаруживают связи с нефтяными и газонефтяными залежами и могут служить индикаторами потенциальной нефтегазоносности территории. Грязевой вулканизм связан с тектоническими участками, которые характеризуются повышенной сейсмической активностью. Во всех случаях, явления грязевого вулканизма возникают в районах относительно слабо расчлененного предгорного рельефа, где накопились мощные (сотни и тысячи метров) толщи преимущественно глинистых пород. В составе газов преобладает метан, имеется также небольшое количество углекислоты и сернистых газов.

Газовые факелы (сипы) образуются в результате интенсивного потока свободного газов с поверхности дна, локализованного своеобразным кратером. Выходы газовых струй формируются в условиях отсутствия мощных толщ покровных глинистых осадков. Газовые сипы постоянно испускают метан со дна моря в толщу воды и представляют собой газовые пузыри, которые поднимаются к поверхности восходящей струей морской воды. Диаметры сипов в различных акваториях различны и в среднем находятся в границах от 10 до 40 м. Высота факелов составляет 100-200м (большинство из них не достигает поверхности воды и диффузно распыляется). Чаще всего это небольшие газовые струи или группы газовых струй (до 5, 10, 12), которые образуют своеобразные облака газа вблизи дна. Во многих случаях видна прерывистость газовых факелов, принимающих форму пульсирующего извержение. Характер газовых факелов в разных морях практически одинаков, изменяется лишь мощность струй. Основная масса газовых капель формирует шлейф, поднимающийся к поверхности моря, подобно струе дыма. В процессе подъема капли сначала образуют тонкий жгут, а затем рассеиваются турбулентностью морской среды в вертикальном и горизонтальном направлении и сносятся от места образования течением. Сипы высокой интенсивности выпускают газ виде большого количества свободного газа. В этом случае плотность пузырьков, их размер и скорость подъема гораздо выше, чем в стабильных медленных сипах. Плотные пузырьковые образования и плюмы могут простираться до высоты 200 м в толще воды, а иногда выходить на поверхность. Большинство сипов расположены в переходной зоне между континентальным шельфом и материковым склоном на глубине от 50 до 650 м. [4]

Природные газовые гидраты представляют собой нестабильный минерал, образование и разложение которого зависят от температуры, давления, химического 
Труды Международной конференции «Дегазация Земли: геология и экология - 2018»

состава газа и воды, свойств пористой среды, в которой они образуются, и других факторов Кристаллогидраты, формирующиеся в пластовых условиях, могут быть диспергированы в поровом пространстве без разрушения вмещающих пор и с разрушением их, могут быть в виде частиц размером до 5-12 см, в виде линз небольшого размера и даже в виде хорошо выдержанных, чисто гидратных пластов большой протяженности толщиной до нескольких метров [5]. Газогидраты могут встречаться в природе и в виде цемента, пластин и прожилок. Внешне гидраты газа напоминают спрессованный снег, переходящий в лед, грязный снег, сухой спирт, но могут выглядеть и как изящные кристаллы разнообразной формы. Их макроструктура примерно такая же, как у льда. Кроме того, они могут гореть, легко распадаются на воду и газ при повышении температуры. Встречаются гидраты метана главным образом в океанах и районах вечной мерзлоты на севере. Газогидраты в чистом виде могут залегать как на дне, так и под дном моря несколькими слоями толщиной от 0,5 до 5 м. При этом, по имеющимся оценкам, 9798 \% мировых запасов газогидратов сосредоточено в морях и океанах, и только 2-3 \% - на суше в зоне вечной мерзлоты.

Газовая составляющая газогидратов на 95\% представлена метаном. Для образования газогидратов необходимы: низкие температуры и высокое давление. При увеличении мощности осадков в море, или при погружении или уменьшении мощности мерзлоты, гидрат метана распадётся, и на небольшой глубине образуется газовый резервуар, из которого газ может прорываться на поверхность. Широкое распространение подводных вулканов и газогидратов в донных отложениях морей и океанов помимо позитивной возможности прироста запасов углеводородов создает важнейшую серьезную проблему для промышленного освоения шельфа и эксплуатации месторождений. Разжижение грунта, нестабильность газогидратных отложений являются сложнейшей инженерной задачей при постройке нефтяных платформ и прокладке трубопроводов.

Важное место выбросы метана занимают в обеспечении геоэкологической безопасности трасс морского транспорта. В частности, через зоны выбросов проходит трасса Севморпути, где находятся крупные зоны подводных метановых «факелов». Их размеры могут достигать в ширину 1300 метров и более [7 ]. Если в такую зону попадет корабль, он может потерять плавучесть. Здесь же расположены лицензионные участки на углеводороды. Важно это и для оценки потенциала газовых месторождений на шельфе. 
Актуальные проблемы нефти и газа • Вып. 4(23) 2018 • http://oilgasjournal.ru

Труды Международной конференции «Дегазация Земли: геология и экология - 2018»

Глубинными источниками метана, мигрирующего по рифтовым разломам вверх, являются крупные нефтегазовые залежи осадочных бассейнов арктического шельфа.

Наряду с геологическими источниками важное место при космическом мониторинге отводится геоэкологическим аспектам нефтегазообразования, которые в своей массе связанны с источниками техногенного воздействия. Ежегодно в океан попадают более 6 млн тонн нефти. Основными источниками загрязнения морской среды являются аварии танкеров, шельфовая добыча нефти, судоходство и морская деятельность. Ежегодно при обычных морских перевозках, авариях и незаконных сбросах в океаны попадает примерно 600000 тонн нефти [3]

Источниками геоэкологических нефтегазопроявлений являются: грифоны газа при бурении скважин, аварии подводных газопроводов и нефтепроводов, аварии ствола нефтяных скважин, судовые разливы, речной сток и исторические аварии.

Газонефтеводопроявления и грифонообразования проиходящие при бурении и экс ᄀплуатации нефтяных и газовых скважин. Бурение, особенно вскрытие продуктивного газового пласта, при некоторых обстоятельствах может привести к значительному по ᄀступлению флюида в скважину в процессе бурения и в заколонное пространство после цементирования. В некоторых случаях поступление флюида может перейти в газонефтеводопроявления с последующим развитием в грифоны, газовые или нефтяные фонтаны, наносящие огромный экологический и экономический ущерб.

В настоящее время нефть - самое распространенное вещество, загрязняющее природные воды. Объемы транспортировки нефти и нефтепродуктов на танкерах оценивается в 1,5 млрд тонн в год. Известно, что 0,03\% транспортируемой танкерами нефти и нефтепродуктов теряется по различным причинам. Разлитая нефть покрывает поверхность моря, растворяется в толще его вод, оседает на дно и, как правило, выплескивается на берег.

Расчет частоты и размеров разливов нефти в результате аварий танкеров в море базируется на статистике ИМО, согласно которой частота аварий составляет (для морей с интенсивным судоходством): посадка на мель - 5,4 на 106 миль; столкновение - 1,9 на 106 миль; повреждение конструкции - 0,48 на 106 миль; пожар, взрыв - 0,063 на 106 миль.

В РГУ нефти и газа (НИУ) имени И.М. Губкина на кафедре геоэкологии проводят исследования, направленные на создание технологий автоматизированного космического мониторинга нефтезагрязнений на шельфе морских акваторий (рис.1). В основу работ 
Труды Международной конференции «Дегазация Земли: геология и экология - 2018»

положено создание единой геоинформационной среды источников нефтегазопроявлений, учитывающей геологические и геоэкологические аспекты их образования. Она строится на основе создания Базы данных поисковой системы, объединяющей известные данные о их наличии из всей открытых источников информации.

Результатом этих исследований стало создание в РГУ нефти и газа (НИУ) им. И.М. Губкина, совместно с «Агентством Геоинформатики и Риска», геоинформационной среды опытного образца технологической платформы АГИР-ТМ («Аэрокосмос, Геоинформатика, Изыскания, Риски - Технологические Модули»). В ее состав входит поисковая система и технологические модули обеспечивающие: геопозиционирование, интерпретацию, моделирование и визуализацию.

Поисковая система, работающая на основе созданной Базы данных, осуществляет поиск объектов нефтегазового комплекса (НГК) по названию региона и по координатам на различных подложках: глобусе; карте. На данный момент в «Базе данных», содержится координатная привязка порядка 6000 объектов по различным странам и регионам.

Модуль геопозиционирования обеспечивает работу с растровыми и векторными данными, и обеспечивает координатную привязку и инвентаризацию интересующих объектов, Инвентаризация осуществляется по картам и снимкам.

Модуль интерпретации выполняет перевод растрового представления изображений в векторные модели. Он обеспечивает векторизацию карт и растровых изображений в визуальном и автоматизированном режимах.

Модуль моделирования предназначен для построения геопространственных и объектно-ориентированных моделей (проектных, ситуационных, мониторинговых). Он осуществляет построение 2D и 3D моделей объектов и процессов в статике и динамике.

Модуль визуализации позволяет отображать модели геоинформационной среды на средствах визуализации в статике и динамике.

В ходе практической апробации изложенного в статье подхода проведения геоэкологических исследований построения геоинформационной среды проектов на основе дистанционционных методов была проведена оценка нефтепроявлений на акваториях морских месторождений нефти и газа (рис.4). 

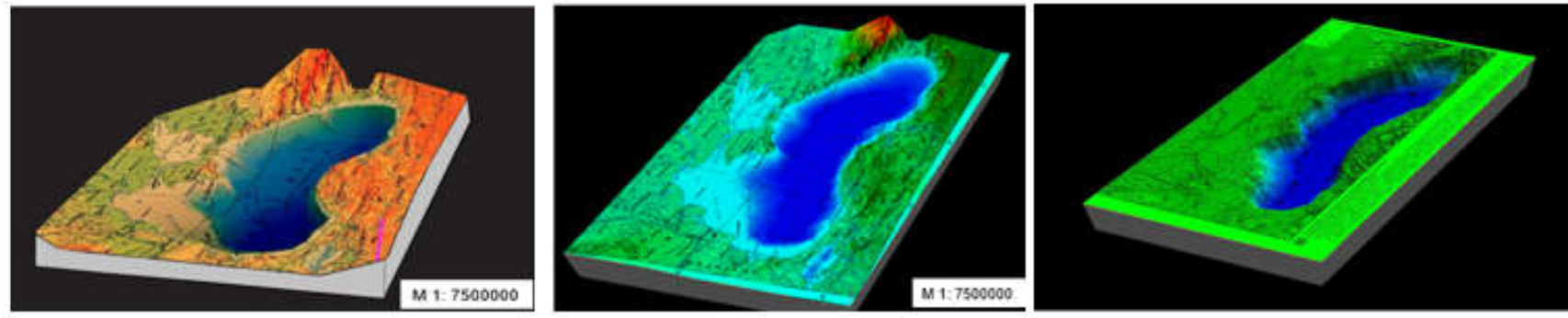

a) Территориальная модель акватории Черного моря

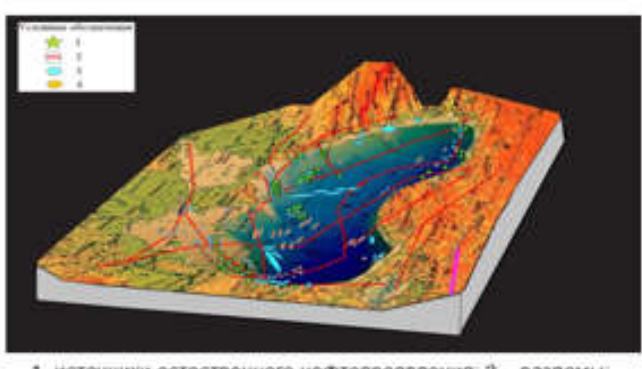

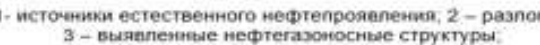
3. - вылапениые нефтегазоносные структуры:

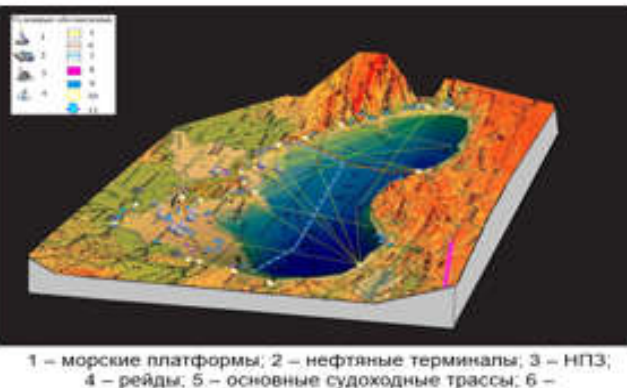

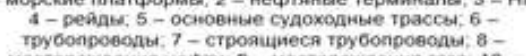

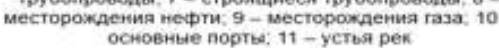

б) Проектная модель инвентаризации
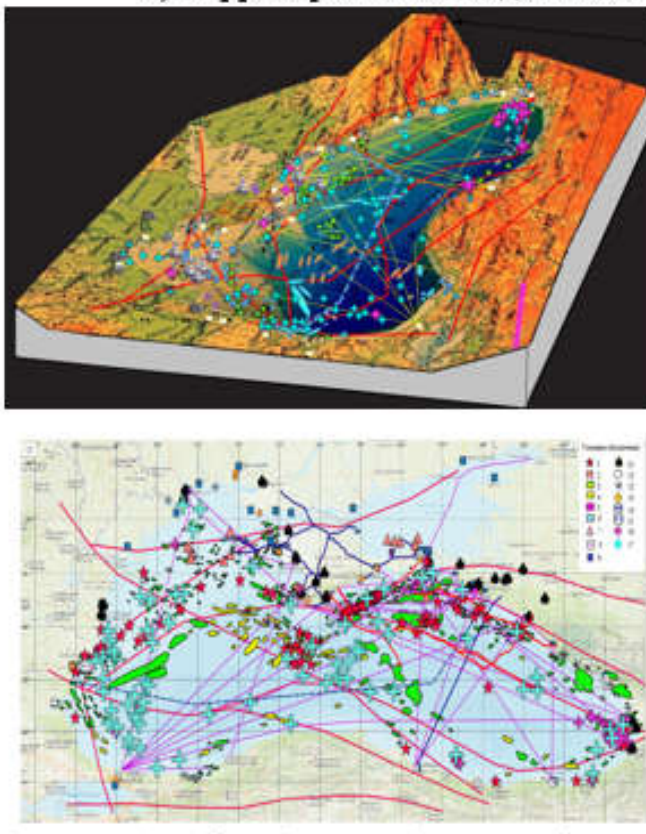

-

в) Ситуационная модель нефтепроявлений

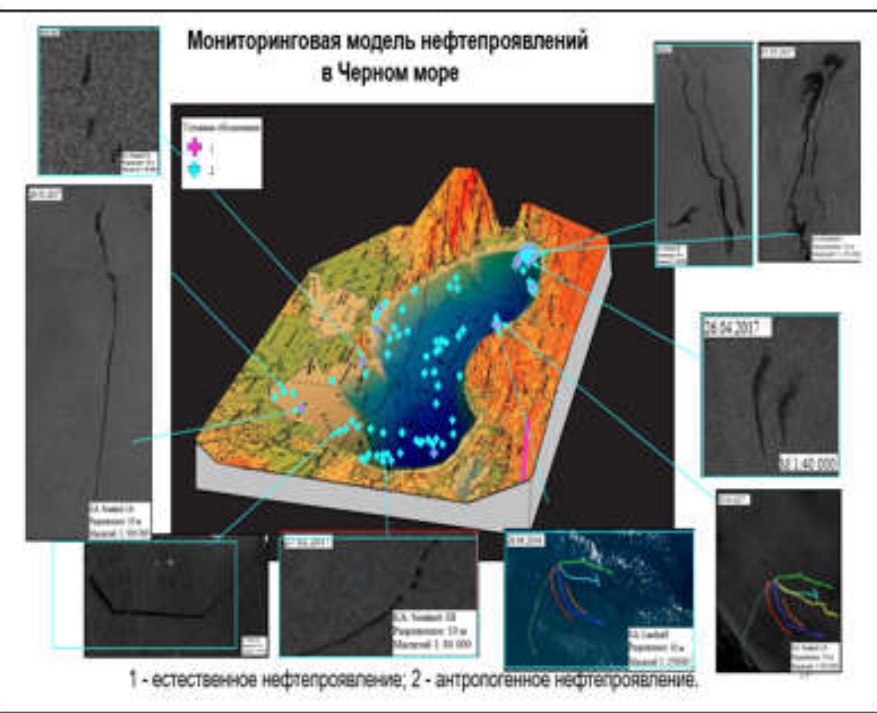

в) Мониторинговая модель нефтепроявлений

Рис. 4 Геоинформационная среда исследований мониторинговых наблюдений нефтегазопроявлений на Черном море 
Актуальные проблемы нефти и газа • Вып. 4(23) 2018 • http://oilgasjournal.ru

Труды Международной конференции «Дегазация Земли: геология и экология - 2018»

Представленные в работе результаты разработки геоинформационной среды ориентированы на повышение эффективности работы с материалами ДЗ3 в задачах управления проектами нефтегазового комплекса. Особое место они занимают при реализации технологии космических мониторинговых наблюдений нефтегазопроявлений в задачах поиска залежей нефти и газа на шельфе морских акваторий, а также контроля нефтезагрязнений морских акваторий при добыче и транспортировке нефти и газа. Важное место в этих работах отводится геоэкологическим исследованиям оценки природных и техногенных рисков, непосредственно оказывающих влияние на безопасность функционирования морских платформ. Создание геоинформационной среды является начальным этапом построения технологической платформы реализации процессов интерпретации и моделирования результатов мониторинговых наблюдений с целью оценки реального состояния исследуемых объектов и процессов. Использование совокупности априорно подготовленных моделей исследуемых объектов позволяет перейти к выполнению обработки материалов Д33 в автоматизированном и автоматическом режимах, что существенно сокращает время обработки поступающей информации и повышает надежность работы всей системы управления.

\section{ЛИТЕРАТУРА}

1. Аковецкий В.Г. Аэрокосмический мониторинг месторождений нефти и газа. ООО «Недра-Бизнесцентр»,2008, 454 с.

2. Бондур, В.Г., Кузнеиова Т.В. 4.4. Исследование естественных нефте- и газопроявлений на морской поверхности по космическим изображениям . Аэрокосмический мониторинг объектов нефтегазового комплекса. Под редакцией академика В.Г. Бондура.М.:Научный мир, 2012, 558c.

3. Воробьев Ю.Л., Акимов В.А., Соколов Ю.И. Предупреждение и ликвидация аварийных разливов нефти и нефтепродуктов. - М.: Ин-октаво, 2005. - 368 с.

4. Дмитриевский А.Н., Баланюк И.Е. Газогидраты морей и океанов. М.: ООО «ИРЦ Газпром». 2009. 416 с.

5. Керимов В.Ю., Сенин Б.В., Богоявленский В.И., Шилов Г.Я. Геология, поиски и разведка месторождений углеводородов на акваториях Мирового океана. Недра, Москва, 2016, $411 \mathrm{c}$. 
6. Якушев В.С., Гафаров Н.А, Карнаухов С.М., Рьбальченко В.В., Огородников И.В., Газовые гидраты в Арктике и Мировом океане: особенности залегания и перспективы освоения. М.: ООО «Издательский дом Недра», 2014 г, 251 с.

7. Лобковский Л.И. Метановое дыхание Арктики. Редкие Земли. 2018, №1, с.2431.

8. Иванов А.Ю. Слики и пленочные образования на космических радиолокационных изображениях // Исслед. Земли из космоса, 2007. № 3. С. 73-96.

9. Ивонин Д.В. , Brekke C. , Skrunes S., Иванов A.Ю. Метод определения типа морс-кого морского слика с помощью соосно-поляризационных снимков радара синтезированной апертуры RADARSAT-2. Институт океанологии им. П.П. Ширшова PAH, Москва, Department of Physics and Technology, University of Tromso - The Arctic University of Norway. XXIX Симпозиум по радиолокационному зондированию природных сред 25-26 марта 2015, Санкт-Петербург.

10. Холл M. Разведка морской прибрежной зоны компанией «AIRBUS DEFENCE». Планетарный характер утечек нефти. Земля из космоса. 2016, №6, с.14-17. 